\title{
Introduced alien signal crayfish (Pacifastacus leniusculus) in Finland - uncontrollable expansion despite numerous crayfisheries strategies
}

\author{
Timo J. Ruokonen ${ }^{1, *}$, Rosanna Sjövik ${ }^{1}$, Esa Erkamo ${ }^{2}$, Jouni Tulonen ${ }^{3}$, Fabio Ercoli ${ }^{4}$, Harri Kokko ${ }^{5}$ and \\ Japo Jussila ${ }^{5}$ \\ ${ }^{1}$ University of Jyväskylä, Department of Biological and Environmental Science, P.O. Box 35, 40014 Jyväskylä, Finland \\ ${ }^{2}$ Natural Resources Institute Finland, 31600 Jokioinen, Finland \\ ${ }^{3}$ Natural Resources Institute Finland, 40500 Jyväskylä, Finland \\ ${ }^{4}$ Centre for Limnology, Institute of Agricultural and Environmental Sciences, Estonian University of Life Sciences, Kreutzwaldi 5, \\ 51014 Tartu, Estonia \\ ${ }^{5}$ University of Eastern Finland, Environmental and Biological Sciences, Kuopio campus, P.O. Box 1627, 70211 Kuopio, Suomi-Finland
}

\begin{abstract}
In Finland, massive signal crayfish introductions started towards the end of 1980s, with an estimated total of 2.2 million signal crayfish been stocked before year 2016. During that period, Finnish fisheries authorities have implemented three national management strategies setting guidelines for the crayfish introductions. The main aims of the strategies have been conservation of native noble crayfish stocks and a controlled spreading of the alien signal crayfish within a designated region. In this study, we report the current distribution of signal crayfish in Finland in comparison to the guidelines set in these three national strategies. The present distribution area of the signal crayfish covers most of the Southern Finland. The signal crayfish has been introduced with a stocking permits to over 480 water bodies. In addition, there have been numerous stockings without permits, which are often next to the region designated for signal crayfish. Based on the results, we conclude that crayfisheries strategies adopted in Finland have only had limited effect on the spread of signal crayfish. We presume that main causes for the uncontrolled spreading of the signal crayfish in Finland have been lack of strict official supervision and general lack of awareness about the risks associated with the alien species spreading.
\end{abstract}

Keywords: dispersal / introduction / management / non-native crayfish / strategy

Résumé - L'écrevisse signal introduite en Finlande (Pacifastacus leniusculus) - expansion incontrôlable malgré de nombreuses stratégies de pêche à l'écrevisse. En Finlande, l'introduction massive d'écrevisses a commencé vers la fin des années 1980, avec un total estimé à 2,2 millions d'écrevisses signal stockées avant 2016. Au cours de cette période, les autorités finlandaises de la pêche ont mis en œuvre trois stratégies nationales de gestion fixant des lignes directrices pour l'introduction des écrevisses. Les principaux objectifs de ces stratégies ont été la conservation des stocks indigènes d'écrevisses nobles et la diffusion contrôlée des écrevisses exotiques dans une région désignée. Dans cette étude, nous présentons la répartition actuelle des écrevisses en Finlande par rapport aux lignes directrices établies dans ces trois stratégies nationales. L'aire de distribution actuelle de l'écrevisse signal couvre la majeure partie du sud de la Finlande. L'écrevisse signal a été introduite avec autorisation dans plus de 480 plans d'eau. De plus, il y a eu de nombreux cas sans permis, souvent à proximité de la région désignée pour les écrevisses signal. Sur la base des résultats, nous concluons que les stratégies de gestion des écrevisses adoptées en Finlande n'ont eu qu'un effet limité sur la propagation des écrevisses signal. Nous présumons que les principales causes de la propagation incontrôlée de l'écrevisse signal en Finlande sont le manque de surveillance officielle stricte et le manque général de sensibilisation aux risques associés à la propagation des espèces exotiques.

Mots-clés : dispersion / introduction / gestion / écrevisse non indigène / stratégie

\footnotetext{
*Corresponding author: timo.j.ruokonen@jyu.fi
} 


\section{Introduction}

Human-mediated introductions are one of the main ways of dispersal of alien species to new areas (Hulme, 2009). Several freshwater crayfish species have been intentionally spread beyond their native range for the aquaculture purposes or for improving the economic value of fisheries (Lodge et al., 2000; Crandall and Buhay, 2008). In Europe, species from North America (e.g., Orconectes limosus, Pacifastacus leniusculus and Procambarus clarkii) are the most widely spread nonnative crayfish (Barbaresi and Gherardi, 2000; Holdich et al., 2009; Kouba et al., 2014). Signal crayfish (P. leniusculus) has been introduced to over 20 European countries (Kouba et al., 2014) and its range expansion is the widest among invasive crayfish in Europe (Chucholl, 2016). It is widely spread in Sweden and Finland where abundant populations support a commercially and recreationally important fishery (Ackerfors, 1999; Jussila and Mannonen, 2004; Souty-Grosset et al., 2006; Jussila et al., 2015b).

Non-native crayfish can have strong negative impacts on native species richness and they can change the structure of freshwater ecosystems in many ways. Non-native crayfish compete with native crayfish and fish for food and shelter (Guan and Wiles, 1997; Griffiths et al., 2004). They reduce the abundance and diversity of macroinvertebrates (Nystrom et al., 1999; McCarthy et al., 2006; Ruokonen et al., 2014). Increased predation of eggs and larvae can alter survival of endangered fish and reptile populations (Mueller et al., 2006; Cruz and Rebelo, 2007). Many freshwater crayfish are also powerful ecosystem engineers and could cause dramatic changes in physical habitat structure by grazing macrophytes and burrowing into banks (Rosenthal et al., 2006; Holdich et al., 2009). Non-native species can also carry a load of diseases and parasites which are often novel to the environment (Ohtaka et al., 2005; Desprez-Loustau et al., 2007). The most serious consequence of introduction of nonnative crayfish to Europe has been the spread of the crayfish plague disease agent (Aphanomyces astaci) (Holdich et al., 2009; Jussila et al., 2015a). It is often carried by the North American crayfish as a chronic infection (Souty-Grosset et al., 2006; Holdich et al., 2009) but it causes a lethal disease to European freshwater crayfish (Edgerton et al., 2004). Realization of harmfulness of alien crayfish has led to reevaluations of introduction and management policies in many countries (e.g., Lodge et al., 2000; Harlioglu and Harlioglu, 2006), and recently also on European Union level, where a new regulation adopted in 2014 and entered into force from January 2015 onwards, intents to tackle the cross-border invasive alien species issues (European Commission Regulation, 1143/ 2014).

In Finland, the first experimental introductions of the alien signal crayfish in selected water bodies took place in the end of 1960s (Westman, 1973), aimed for gathering information for a detailed introduction plan. This attempt was carried out because of the poor recovery of the native crayfish (Astacus astacus) populations after repeated crayfish plague outbreaks. Massive introductions of signal crayfish started towards the end of 1980s (Erkamo et al., 2010). During the 1990s and 2000s over two million signal crayfish were released into Finnish lakes and rivers mostly in southern part of Finland
(Erkamo et al., 2010). It has been estimated by the Finnish Game and Fisheries Research Institute that over $80 \%$ of the signal crayfish introductions resulted in naturally reproducing populations, and nowadays this species can be treated as a permanent resident in hundreds of Finnish lakes and rivers (Erkamo et al., 2010). However, several productive signal crayfish populations have recently collapsed in Southern Finland, and in Sweden, indicating unexpected instability and sensitivity for environmental variation and diseases in signal crayfish (Aydin et al., 2014; Jussila et al., 2014; Sandström et al., 2014; Jussila et al., 2015a).

The Finnish fisheries authorities have implemented specific management strategies setting guidelines for the crayfish introductions, amongst other related issues, since 1989 (Tab. 1). The main aims of these non-mandatory strategies have been conservation of native noble crayfish stocks and so called controlled spreading of the alien signal crayfish within designated regions (Fig. 1, Tab. 1). In this paper we report the current documented distribution of alien signal crayfish in Finland in comparison to the guidelines set for the planned spreading in the national crayfisheries strategies. Further, to review the effectivity of strategies, we investigate the number of signal crayfish populations outside the region designated for signal crayfish among three strategy periods from 1989 to 2015 (Fig. 1, Tab. 1). Based on these results, we also give an estimate of the possible signal crayfish spreading in the future and discuss how to limit its further spreading.

\section{Material and methods}

Signal crayfish distribution data were gathered from various sources. Data from official introduction register maintained by government fisheries organisations, which include all registered crayfish introductions with a permit (Tab. 1), represents official legal introductions in our data. Data of unlicensed and illegal introductions were collected from various sources including official databases maintained by government fisheries organisations and surveys made for regional Fisheries Advisory Centres and similar organisations representing stakeholders. Data includes also observations collected from various alternative sources, e.g., from fishing rights owners, private persons and research personnel. Only reliable and verified observations with information of location, observation year (in some uncertain cases estimated in five years accuracy), and information of legality were included to data which was then combined with the official statistical data and the combined information then used to assess the efficiency of strategies.

Our data includes large lakes and long river systems with several introductions treated as separate cases and other stocking observations to sites in one watercourse but far apart (crayfish could not be assumed to move naturally between sites in observed time scale, distance between sites $>20 \mathrm{~km}$ ), both of which were also classified as new discoveries of signal crayfish populations. Signal crayfish observations inside or outside of regions designated for signal crayfish in different strategies were inspected on the maps based on existing data. Geographical distribution maps and regions designated for signal crayfish were produced using ArcMap (10.3.1) program. 
T.J. Ruokonen et al.: Knowl. Manag. Aquat. Ecosyst. 2018, 419, 27

Table 1. National crayfisheries strategies and management guidelines related to signal crayfish in Finland.

\begin{tabular}{|c|c|c|c|c|c|c|}
\hline & Time & Aim & $\begin{array}{c}\text { Area } \\
\text { designed for } \\
P . \\
\text { leniusculus }\end{array}$ & $\begin{array}{l}\text { Rationale for area } \\
\text { selection }\end{array}$ & $\begin{array}{l}\text { Conditions for } \\
P . \text { leniusculus } \\
\text { introductions }\end{array}$ & $\begin{array}{c}\text { No. of } P \text {. } \\
\text { leniusculus } \\
\text { introduced with } \\
\text { permit }\end{array}$ \\
\hline $\begin{array}{l}\text { Experimental } \\
\text { introductions }\end{array}$ & $1967-1988$ & $\begin{array}{l}\text { To test } P \text {. leniusculus } \\
\text { suitability under } \\
\text { Finnish conditions }\end{array}$ & $155 \mathrm{~km}^{2}$ & $\begin{array}{l}\text { Small and midle size } \\
\text { lakes, rivers and brackish } \\
\text { water inlets }\end{array}$ & $\begin{array}{l}\text { No specific } \\
\text { regulations }\end{array}$ & 86400 \\
\hline 1st strategy & 1989-2000 & $\begin{array}{l}\text { Conservation of } A \text {. } \\
\text { astacus; controlled } \\
\text { spreading of } P . \\
\text { leniusculus }\end{array}$ & $6200 \mathrm{~km}^{2}$ & $\begin{array}{l}\text { Waters previous inhabited } \\
\text { by } \text { A.astacus in southern } \\
\text { Finland, spreading } \\
\text { resctricted within natural } \\
\text { catchments }\end{array}$ & $\begin{array}{l}\text { No threat for } A \text {. } \\
\text { astacus; } \\
\text { material free of } \\
\text { A.astaci; } \\
\text { introduction } \\
\text { needed always } \\
\text { a permission }\end{array}$ & 1511500 \\
\hline 2nd strategy & 2001-2013 & $\begin{array}{l}\text { Conservation of } A \text {. } \\
\text { astacus; controlled } \\
\text { spreading of } P . \\
\text { leniusculus }\end{array}$ & $7200 \mathrm{~km}^{2}$ & $\begin{array}{l}\text { Area defined in the } 1 \text { st } \\
\text { management strategy } \\
\text { further extended to cover } \\
\text { established populations }\end{array}$ & $\begin{array}{l}\text { No threat for } A \text {. } \\
\text { astacus; } \\
\text { material free of } \\
\text { A.astaci; } \\
\text { introduction } \\
\text { needed always } \\
\text { a permission }\end{array}$ & 570700 \\
\hline 3rd strategy & 2014-2016 & $\begin{array}{l}\text { Conservation of } A \text {. } \\
\text { astacus; controlled } \\
\text { spreading of } P \text {. } \\
\text { leniusculus }\end{array}$ & $19700 \mathrm{~km}^{2}$ & $\begin{array}{l}\text { Area defined in the } 2 \text { nd } \\
\text { management strategy } \\
\text { further extended to cover } \\
\text { established populations }\end{array}$ & $\begin{array}{l}\text { No threat for } A \text {. } \\
\text { astacus; } \\
\text { material free of } \\
\text { A.astaci; } \\
\text { introduction } \\
\text { needed always } \\
\text { a permission, } \\
\text { not given in } \\
\text { catchments with } \\
\text { only small lakes } \\
\text { ( }<500 \text { ha) }\end{array}$ & 35900 \\
\hline
\end{tabular}

\section{Results}

After first signal crayfish introductions in 1967, during the so called experimental introduction phase, the introduction rate was rather low until the end of 1980s (Fig. 2a, b). In total, before drafting the $1 \mathrm{st}$ crayfisheries strategy (i.e., during years 1967-1989), there were licenced signal crayfish introductions to 61 separate water bodies (Tab. 2), been carried out mostly by fisheries research authorities. These waters for the first introductions were selected mostly from Uusimaa, Tavastia Proper and Pirkanmaa regions (Fig. 3a). However, signal crayfish were legally introduced also to several isolated water bodies across Finland during years 1967-1989 (Fig. 3a). The first two unlicensed introductions were recorded in Uusimaa and Kymenlaakso regions in 1985 and 1986 (Fig. 2a, Fig. 3a).

After the experimental introductions, fishing rights owners initiated introductions in late 1980 s especially in Tavastia Proper region (Fig. 3b). That lead to rapid increase in the number of the water bodies introduced with signal crayfish in Uusimaa, Tavastia Proper, Päijänne Tavastia and South Karelia regions during 1990s (Fig. 3b). During 1989-2000, following the guidelines been set by the 1st crayfisheries strategy, a total of 343 licensed introductions had been carried out into individual water bodies (Fig. 2b, Fig. 3b). Unlicensed introductions were increasingly registered during that period (Fig. 2A), with reports of unlicenced introductions from 70 waters of which 20 were situated outside the region designated for signal crayfish (Fig. 3b, Tab. 2). Most of the unlicensed sites situated close to region designated for signal crayfish while also isolated introductions were observed around eastern Finland (Southern and Northern Savonia and North Karelia) up to $300 \mathrm{~km}$ distance from area designated for signal crayfish (Fig. 3B).

After the first revision of the national crayfisheries strategy in year 2000, an era of numerous unlicensed introductions of the signal crayfish was initiated. From year 2001-2013, there was a total of 78 licensed introductions into novel water bodies, while a total of 282 unlicensed introductions were reported (Fig. 2a, Tab. 2). From those, 79 were outside the region designated for signal crayfish as specified in 2 nd crayfisheries strategy (Fig. 3c, Tab. 2). Most of these unlicensed introductions were again close to the region designated for signal crayfish while also increasing number of sites were registered from Central Finland, Northern Savonia and Northern Karelia regions (Fig. 3c).

After the second revision of the national crayfisheries strategy in year 2013, only two new water bodies with licensed 


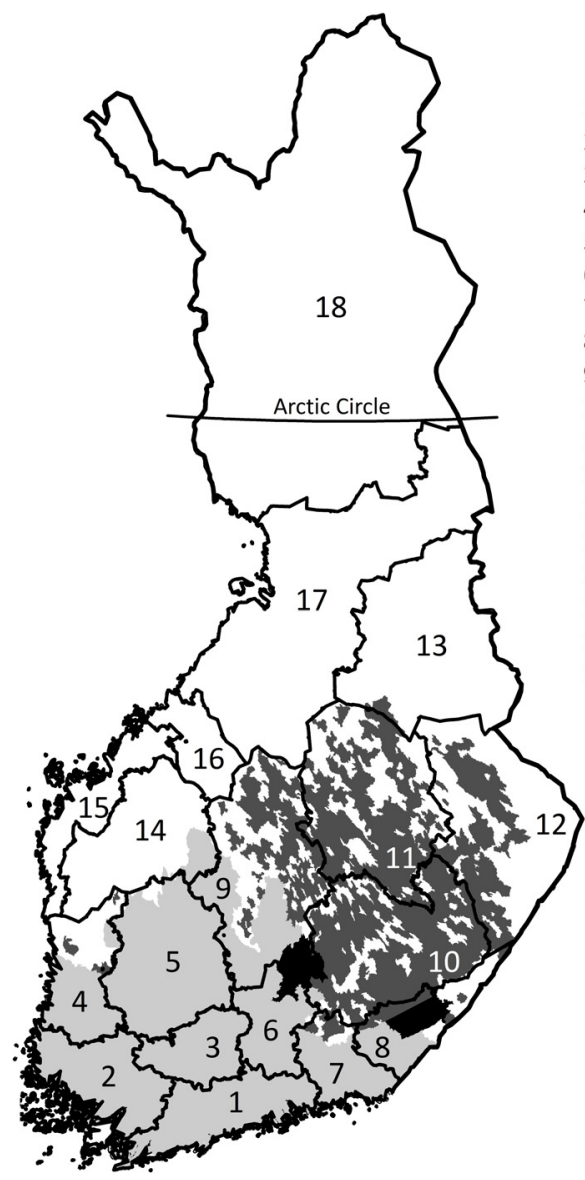

1 Uusimaa

2 Southwest Finland

3 Tavastia Proper

4 Satakunta

5 Pirkanmaa

6 Päijänne Tavastia

7 Kymenlaakso

8 South Karelia

9 Central Finland

10 Southern Savonia

11 Northern Savonia

12 North Karelia

13 Kainuu

14 Southern Ostrobothnia

15 Ostrobothnia

16 Central Ostrobothnia

17 Northern Ostrobothnia

18 Lapland

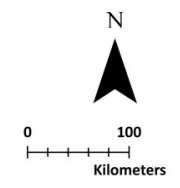

Fig. 1. Regions designated for signal crayfish in Finland according to three national crayfisheries strategies. Regions designated in 1st crayfisheries strategy (1989) marked in light grey, year 2000 additions in black and year 2013 additions in dark grey. Governmental regions are indicated by numbers.

introductions and a total of 34 unlicensed introductions of the signal crayfish have been observed, of which four were outside the expanded region designated for signal crayfish (Fig. 3d, Tab 2). Hence, the present distribution of the alien signal crayfish covers southern parts of Finland (Fig. 4).

In total, the alien signal crayfish has been introduced with an introduction permit (licensed introductions) to over 480 water bodies (Fig. 2b, Fig. 4).

In addition, there have been numerous introductions of the alien signal crayfish without a permit within and beyond the region designated for signal crayfish (Tab. 2). In total, unlicensed introductions have been reported from 388 water bodies (Fig. 2B, Fig. 4) of which 283 observations are from waters inside the region designed for signal crayfish (Tab. 2). Respectively, 103 observations have been reported from waters outside region designed for signal crayfish. In 2nd crayfisheries strategy revision in year 2000, $11 \%$ of the unlicensed introductions (carried out between years 19892000), which were outside the region designated for signal crayfish in the 1 st crayfisheries strategy (Fig. 3b), were included in the new area extension (Fig. 3c). Most of the unlicensed introductions outside the region designated for signal crayfish were recorded from year 2001-2013 during the 2nd crayfisheries strategy (Tab. 2). A total of $58 \%$ of those sites were included in the second area extension in the 3rd crayfisheries strategy revision in year 2013 (Fig. 3d).

\section{Discussion}

In this study, we show the results of 50 years of introductions of alien signal crayfish in Finland on the background of three national crayfisheries strategies which were, amongst other aims, intended to control alien signal crayfish stockings and spreading. The intentional spreading was managed by three specific crayfisheries strategies (i.e., strategies from years 1989, 2000 and 2013) which all officially aimed to control the spreading of signal crayfish and conserving the only Finnish native crayfish species, the noble crayfish ( $A$. astacus). Our comprehensive distribution data gave a unique opportunity for retrospective evaluation of the effectiveness of management strategies and will give important insights for management of invasive species with economic value and lots of interests among the public.

The number of signal crayfish introductions was rather low during the first 20 years (i.e., 1967-1989), roughly $7 \%$ of total number of stockings happened during that period. In this phase, prior the 1st crayfisheries strategy, signal crayfish introductions were restricted by fisheries authorities mainly to smaller lakes (Järvenpää and Kirjavainen, 1992) which partially explains the slow extension of distribution area during the early stages. However, lakes for these experimental introductions were selected widely across southern and central Finland (Westman, 1973), which might have contributed to wider spreading in forthcoming years.

Early experimental introductions, with adult signal crayfish brought from North America, yielded less than impressive results (Westman, 1973; Westman et al., 1999), which lead to intensive development of farming of signal crayfish and mass production of signal crayfish juveniles for stockings in private farms (Kirjavainen and Sipponen, 2004). Preliminary promising research results from some lakes together with success in juvenile production in larger scale (Kirjavainen and Westman, 1994) raised wide public interest on signal crayfish introductions and need for 1st crayfisheries strategy was recognised by fisheries authorities (Kirjavainen and Sipponen, 2004).

Area designated for signal crayfish in 1st crayfisheries strategy (1989) was defined by natural catchments which were thought to limit the unaided spread of signal crayfish. At that time, signal crayfish was seen as a good replacement for declining or lost noble crayfish stocks among some persons in fisheries administration and researchers (e.g., Westman, 2002) which led to massive introduction programs supported and cofunded by the fisheries authorities (e.g., Jussila et al., 2015a). Signal crayfish introductions still needed permission from government fisheries authorities but within the area designated for signal crayfish permits were given rather liberally. The distribution area of signal crayfish expanded broadly by the licenced introductions between years 1989 and 2000. In total, signal crayfish were introduced to over 340 lakes or rivers by the year 2000 and introductions were also initiated into larger lakes (Erkamo et al., 2010) and long river systems which 

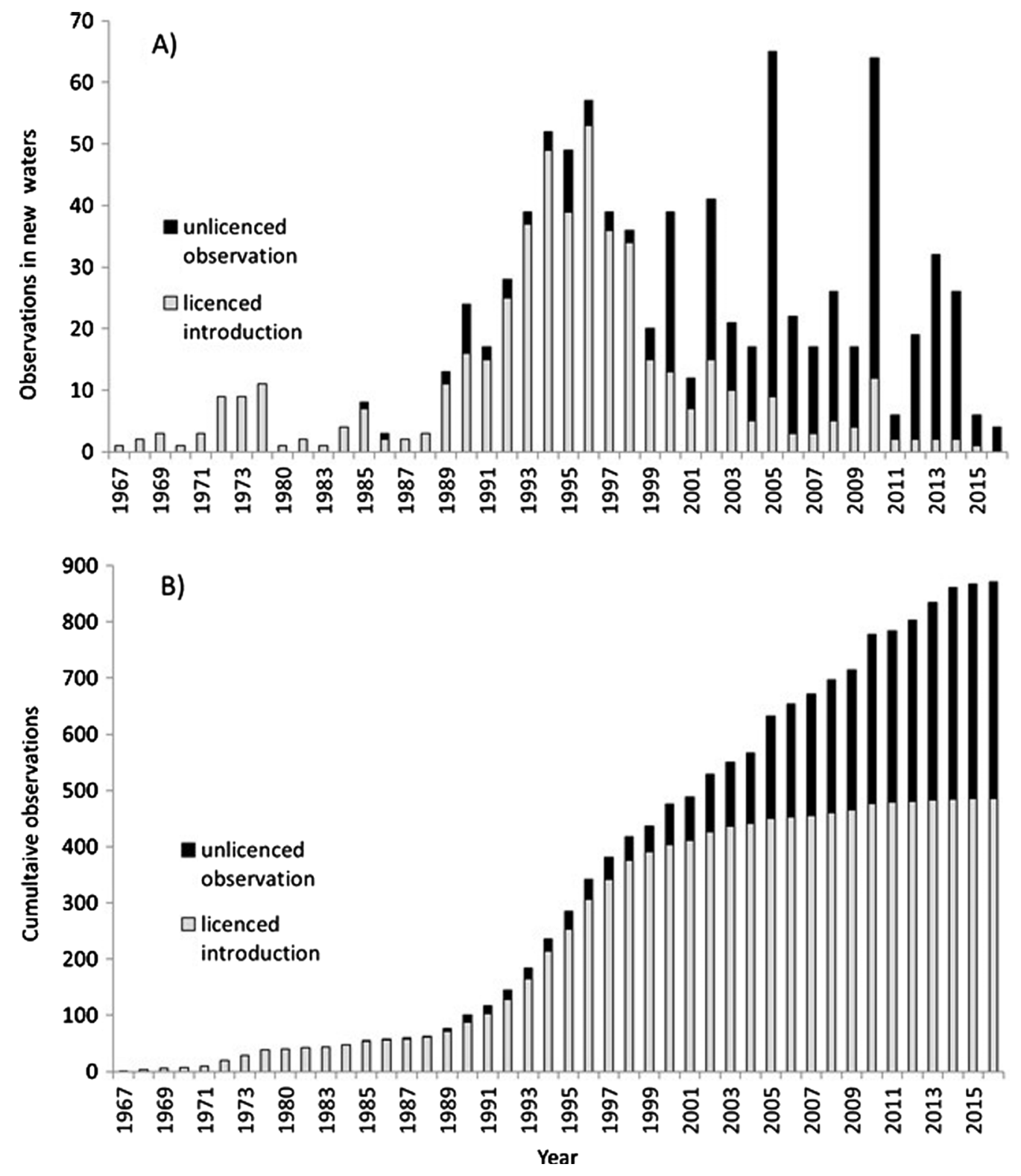

Fig. 2. Licenced signal crayfish introductions and unlicensed observations 1967-2016. a) Observations in new waters for each year, and b) cumulative observations in new waters for each year.

Table 2. The number of waters with licenced signal crayfish introductions and unlicensed observations in Finland according to national crayfisheries strategies. Unlicensed observations are further divided to two categories on the basis of whether they were located inside or outside the region designed for signal crayfish.

\begin{tabular}{|c|c|c|c|c|c|c|}
\hline & \multirow{2}{*}{ Time } & \multirow{2}{*}{ Total } & \multirow{2}{*}{ Licensed } & \multirow{2}{*}{ Unlicensed } & \multicolumn{2}{|c|}{ Unlicensed } \\
\hline & & & & & Inside area & Outside area \\
\hline Experimental introductions & $1967-1988$ & 63 & 61 & 2 & - & - \\
\hline 1st crayfisheries strategy & $1989-2000$ & 413 & 343 & 70 & 50 & 20 \\
\hline 2nd crayfisheries strategy & $2001-2013$ & 360 & 78 & 282 & 203 & 79 \\
\hline \multirow[t]{2}{*}{3 rd crayfisheries strategy } & 2014-2016 & 36 & 2 & 34 & 30 & 4 \\
\hline & Total & 872 & 484 & 388 & 283 & 103 \\
\hline
\end{tabular}



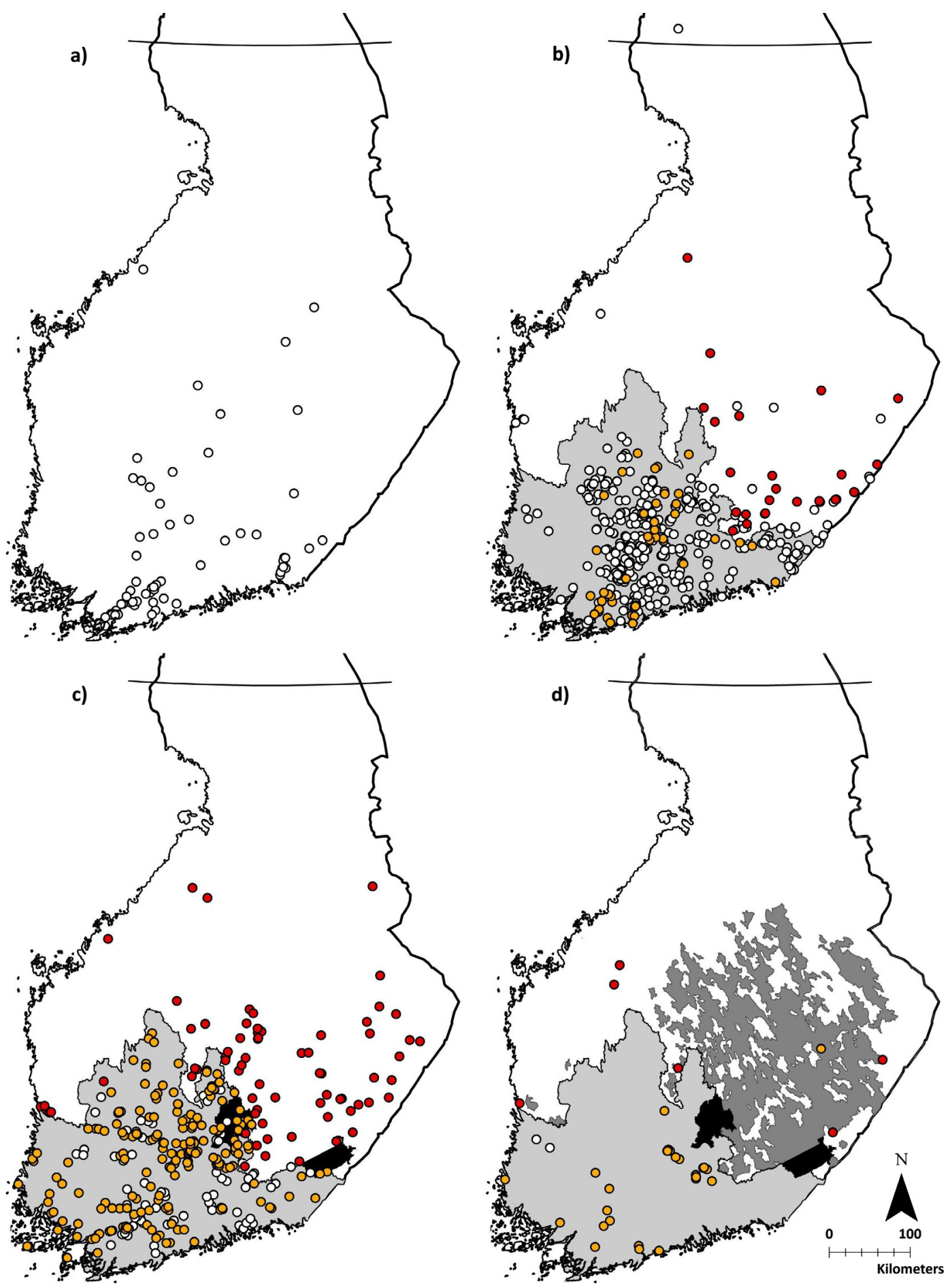

Fig. 3. Licenced signal crayfish introductions (white circles), unlicensed observations inside signal crayfish region (orange circles, and unlicensed observations outside signal crayfish region (red circles) in Finland. a) Before 1989, b) 1st crayfisheries strategy era (1989-2000), c) 2nd crayfisheries strategy era (2001-2013), d) After 3rd crayfisheries strategy 2014-2016). Marked areas represent regions designated for signal crayfish in national crayfisheries strategies.

quickly increased total water surface area inhabited by signal crayfish up to $600 \mathrm{~km}^{2}$.

Our data shows that signal crayfish spreading began to be uncontrollable in late 1990s with numerous unlicensed introductions in Southern and Central Finland. Good results from licenced introductions and easy access to stocking material since late 1990 s probably accelerated unlicensed stocking.
Furthermore, the relaxed attitude within government fisheries administration towards instructions given in official crayfisheries strategies aiming for controlling of the signal crayfish introductions were taken as non-mandatory, and introduction permissions were given also outside of the area designated for signal crayfish in Southern Karelia region. This led to conclusion among government fisheries authorities, in 


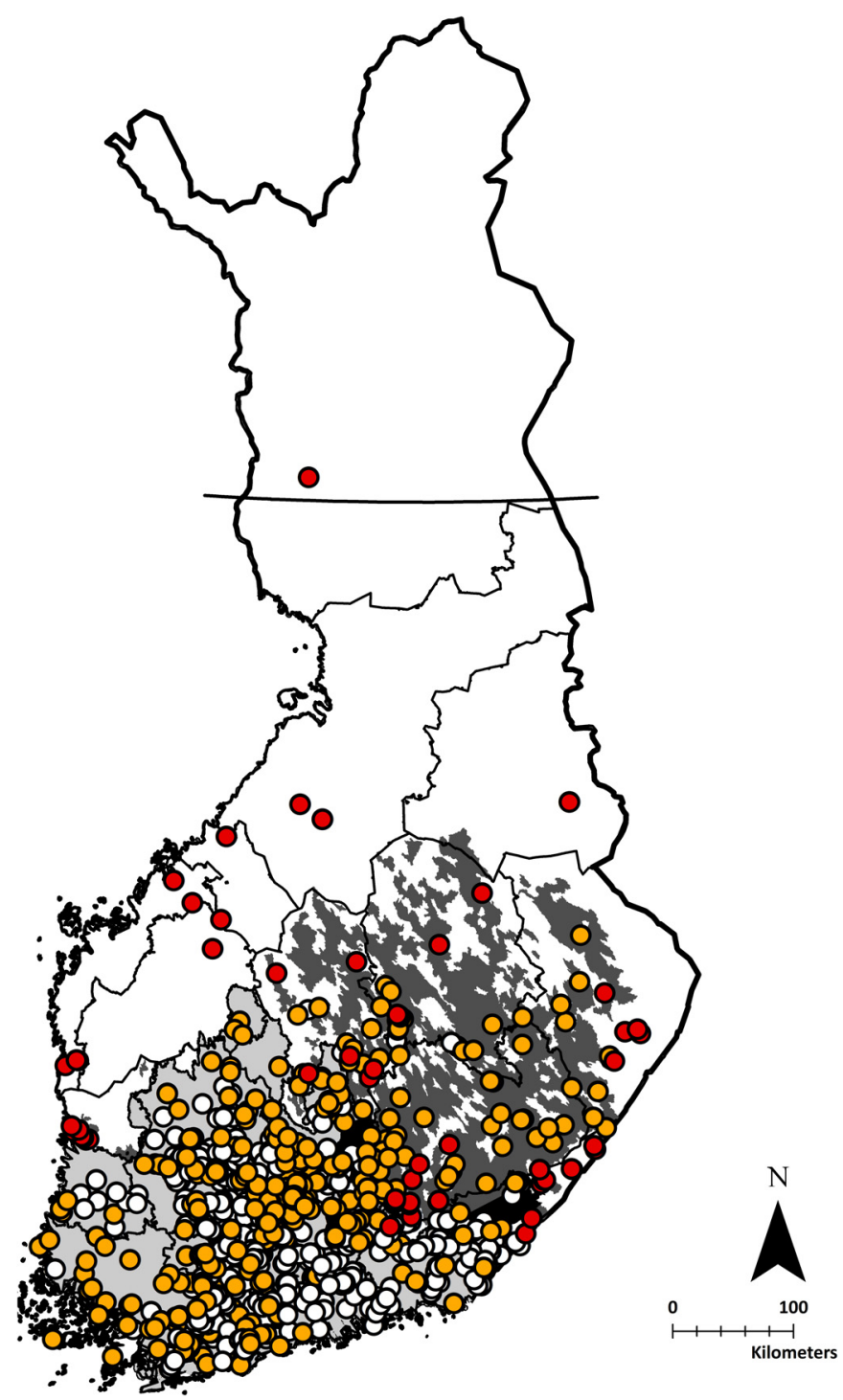

Fig. 4. All recorded signal crayfish introductions (white circles), unlicensed observations inside signal crayfish region (orange circles, and unlicensed observations outside signal crayfish region (red circles) in Finland 1967-2016. Marked areas represent regions designated for signal crayfish in national crayfisheries strategies.

collaboration with several stake holders, to prepare a 2nd crayfisheries strategy in 2000 . The main issues in the 2 nd crayfisheries strategy were again the controlled spreading of signal crayfish and conservation of native noble crayfish. However, in spite of the increase of unlicenced introductions was commonly acknowledged among parties preparing the 2nd crayfisheries strategy, region designated for signal crayfish was expanded in Southern Karelia and Tavastia regions to cover most of the area where unlicenced stockings during previous years had occurred. This administrative decision indicated, amongst other matters, that unlicenced signal crayfish introductions, even though illegal (Jussila et al., 2015b), would later be treated similarly to licenced ones by the government fisheries administration.

After the 2nd crayfisheries strategy, number of new annual licenced introductions slowly decreased. Most of the waters known to be suitable for crayfish and larger southern and central lakes were already stocked with signal crayfish, which largely decreased the need for new stockings within region designated for signal crayfish. Furthermore, first signal crayfish stock collapses were detected in early and middle 2000s (Jussila et al., 2014). It was also acknowledged, that crayfish plague could be a real problem also for the production of signal crayfish populations (e.g., Aydin et al., 2014), not only for noble crayfish as was assumed earlier, which may have restrained licenced introductions to some extent.

Our data shows clearly that uncontrolled spreading of signal crayfish started together with increase of licenced introductions. Year 2002 onwards more unlicensed introductions than licenced introductions have been recorded each year. At the beginning, unlicensed introduction sites were mostly within region designated for signal crayfish. In some, maybe even rare, cases signal crayfish have spread naturally via watercourses outside region designated for signal crayfish, but in most cases the signal crayfish spreading has been assisted by man. In mid 2000s, increasing number of introductions were recorded outside designated region and signal crayfish spread to large lake systems in Southern Savonia, Northern Savonia, and North Karelia. In 3rd crayfisheries strategy (2013), the region designated for signal crayfish was expanded again thus approving the preceeding unlicenced signal crayfish introductions, indicating only limited attempt to restrict further spreading of the signal crayfish. This view is supported by the fact that, to our knowledge, so far no legal actions have been taken over unlicenced (i.e., illegal) stocking of signal crayfish in Finland.

Fifty years after the first introduction, alien signal crayfish have now spread widely to Southern and Central Finland and irreversibly replaced the native noble crayfish in many water courses in Southern Finland. Observed trend of the unlicensed signal crayfish introductions in to the Finnish waters clearly indicates the inefficiency of the non-mandatory strategies and management actions adopted so far to tackle the challenge of uncontrolled spreading of signal crayfish. The 1st crayfisheries strategy (1989) set rather good frame and preconditions for signal crayfish introductions but since not all stakeholders, including government fisheries administration, were committed to follow the non-mandatory guidelines of the 1st crayfisheries strategy (1989), realisation of the strategical guidelines and recommendations were less successful. The trend of ignoring the principle of limiting signal crayfish stockings was adopted and repeatedly utilised when the two latter crayfisheries strategies were drafted and implemented.

In addition to national crayfisheries strategies, legislation (e.g., Fishing Act, Nature Conservation Act, Animal Disease Act), and local crayfisheries management strategies (e.g., regional crayfisheries strategies, fisheries management plans of shareholder associations, Metsähallitus crayfisheries strategy for state owned waters) have given restrictive guidelines for signal crayfish introductions. Thus, we can state that the lack of legislation or strategic guidelines are not plausible explanations for massive number of unlicensed introductions. Instead, we assume that the main causes that allowed the uncontrolled spreading of the signal crayfish in Finland have been the lack of awareness among the public about the real risks and uncertainties associated with the alien signal crayfish spreading, and also the divergent views among fisheries administrators and researchers (Jussila et al., 2015b). These are general reasons which are recognised to deflate invasive species 
management also globally (Souty-Grosset et al., 2016: Piria et al., 2017).

Although the numerous attempts to limit signal crayfish introductions to a restricted area, many unlicenced introductions occurred and we presume that many more Finnish lakes will become occupied by signal crayfish in future. Natural spreading of signal crayfish is slow being some kilometres in a year (Bubb et al., 2004). Lots of natural barriers like watersheds and man-made dams appear in Finnish catchments which prevent or slow the natural spread. In basis of present distribution area, signal crayfish have potential to inhabit all waters, maybe providing human assistance, in southern part of Finland.

Freshwater crayfish tolerate saline water to some extent (e.g., Holdich et al., 1997; Vesely et al., 2017) but have not been reported to reproduce in high salinity waters (Holdich et al., 1997). However, low-saline estuaries and coastal areas could potentially act as invasion corridors between rivers (DobrzyckaKrahel et al., 2017; Vesely et al., 2017). Experimental signal crayfish introduction were carried out in the Finnish coastal area of Baltic Sea (salinity 1.5-6\%o) in 1970's and 1980's, but no observations of established populations have so far been made (Järvenpää T. pers comm). However, potential of brackish water as an invasion corridor for alien crayfish should be further studied across low-saline Baltic Sea.

In general, climate change can greatly facilitate colonization, spreading and establishment of alien species (Walther et al., 2009). Capinha et al. (2013) found that propagule pressure and climate suitability are the most important drivers for signal crayfish distribution in Europe, suggesting that rising temperature due to the climate change together with the human-mediated introduction might facilitate signal crayfish spreading and establishment towards northern parts of Europe. In a basis of literature review, Heinimaa and Pursiainen (2008) proposed that cold climate restricts signal crayfish distribution in Finland and could prevent spreading towards north. In that case, distribution area of signal crayfish could expand due increasing water temperatures in future. However, recent contradicting empirical findings from Sweden suggest that warming could cause several problems (e.g., more diseases, reproduction timing problems, and increased predation) and actually restrict the distribution of signal crayfish distribution in future (Sandström et al., 2014; Bohman et al., 2015). It has also been suggested, that the signal crayfish stock collapses observed in Finland, been mainly in small or shallow lakes, could be partially because of high, not low, water temperature (Jussila et al., 2014). It seems that the effect of climate on distribution of signal crayfish in Northern Europe is a complicated process, which needs more research effort in future.

Signal crayfish will be in Finnish waters to the foreseeable future. It is clear that the total eradication of alien signal crayfish is not possible with any of the means currently available. Therefore actions for minimising negative effects on other biota and for preventing spreading to new areas should be applied. Signal crayfish is now listed as a harmful alien species in list of invasive alien species of European Union concern (EU Regulation 1143/2014), which obligates member states to take actions to minimise the damage by harmful alien species that are already widely spread in their territory.

In Finland more severe restrictions and actions are suggested after EU Regulation 1143/2014 came into effect, including: total ban for stocking and culture of signal crayfish, newly arisen and still weak signal crayfish populations in critical areas should be exterminated as soon as possible, storing alien crayfish beyond catching waters should be strictly regulated and transporting of live alien crayfish should be minimized in a long run. Above all is awakening of general awareness to the risks concerning stocking of alien crayfish. It is generally accepted that prevention is the most effective invasive species management approach. Among many others, Peters and Lodge (2009) concluded that managing vectors (i.e., humans) rather than specific species is a more effective approach to controlling the spread of invasive species. To prevent further spread of signal crayfish in Finnish waters and worldwide, more education and information on the risks posed by alien crayfish is urgently needed for authorities, fisheries managers, and general public.

Acknowledgements. We have been kindly assisted by EU LIFE + CrayMate (LIFE12 INF/FI/233) in our attempts to understand complicated nature related policies. TJR and FE have been funded by Maj \& Tor Nessling Foundation. We also thank Mr. Markku Pursiainen and numerous other people from Finnish Natural Resource Institute for collecting and processing crayfish data. We are also grateful for people in local Centres for Economic Development, Transport and the Environment for access to recent signal crayfish introduction and observation data.

\section{References}

Ackerfors H. 1999. The positive effects of established crayfish introductions in Europe. In: Gherardi F, Holdich DM, eds. Crayfish in Europe as alien species. How to make the best of a bad situation. Rotterdam: A.A. Balkema, pp. 49-61.

Aydin H, Kokko H, Makkonen J, Kortet R, Kukkonen H, Jussila J. 2014. The signal crayfish is vulnerable to both the As and the PsI-isolates of the crayfish plague. Knowl Manag Aquat Ecosyst 413: 10.

Barbaresi S, Gherardi F. 2000. The invasion of the alien crayfish Procambarus clarkii in Europe, with particular reference to Italy. Biol Invasions 2: 259-264.

Bohman P, Edsman L, Sandström A, et al. 2015. Predicting harvest of non-native signal crayfish in lakes - a role for changing climate? Can J Fish Aquat Sci 1-30.

Bubb DH, Thom TJ, Lucas MC. 2004. Movement and dispersal of the invasive signal crayfish Pacifastacus leniusculus in upland rivers. Freshw Biol 49: 357-368.

Capinha C, Brotons L, Anastácio P. 2013. Geographical variability in propagule pressure and climatic suitability explain the European distribution of two highly invasive crayfish. J Biogeogr 40: 548-558.

Chucholl C. 2016. The bad and the super-bad: prioritising the threat of six invasive alien to three imperilled native crayfishes. Biol Invasions 7: 1967-1988.

Crandall K, Buhay JE. 2008. Global diversity of crayfish (Astacidae, Cambaridae, and Parastacidae - Decapoda) in freshwater. Hydrobiologia 595: 295-301.

Cruz MJ, Rebelo R. 2007. Colonization of freshwater habitats by an introduced crayfish, Procambarus clarkii, in Southwest Iberian Peninsula. Hydrobiologia 575: 191-201.

Dana ED, López-Santiago J, García-De-Lomas J, García-Ocaña DM, Gámez V, Ortega F. 2010. Long-term management of the invasive Pacifastacus leniusculus (Dana, 1852) in a small mountain stream. Aquat Invasions 5: 317-322. 
Desprez-Loustau ML, Robin C, Buée M, et al. 2007. The fungal dimension of biological invasions. Trends Ecol Evol 22: 472-480.

Dobrzycka-KrahelA,SkoraME,RaczynskiM,SzaniawskaA.2017.The signal crayfish Pacifastacus leniusculus - distribution and invasion in the southern Baltic coastal river. Pol J Ecol 65: 445-452.

Edgerton BF, Henttonen P, Jussila J, et al. 2004. Understanding the causes of disease in European freshwater crayfish. Conserv Biol 18: $1466-1474$

Erkamo E, Ruokonen T, Alapassi T, et al. 2010. Evaluation of crayfish stocking success in Finland. Freshw Crayfish 17: 77-83.

Griffiths SW, Collen P, Armstrong JD. 2004. Competition for shelter among over-wintering signal crayfish and juvenile Atlantic salmon. $J$ Fish Biol 65: 436-447.

Guan RZ, Wiles PR. 1997. Ecological impact of introduced crayfish on benthic fishes in a British lowland river. Conserv Biol 11: 641-647.

Harlioglu MM, Harlioglu AG. 2006. Threat of non-native crayfish introductions into Turkey: global lessons. Rev Fish Biol Fish 16: $171-181$

Hein CL, Vander ZMJ, Magnuson JJ. 2007. Intensive trapping and increased fish predation cause massive population decline of an invasive crayfish. Freshw Biol 52: 1134-1146.

Heinimaa S, Pursiainen M. 2008. Signal crayfish Pacifastacus leniusculus at northerly latitudes: A search for the distribution limits. Freshw Crayfish 16: 37-41.

Holdich DM, Harlioglu MM, Firkins I. 1997. Salinity adaptations of crayfish in British waters with particular reference to Austropotamobius pallipes, Astacus leptodactylus and Pacifastacus leniusculus. Estuar Coast Shelf Sci 44: 147-154.

Holdich DMM, Reynolds JDD, Souty-Grosset C, Sibley PJJ. 2009. A review of the ever increasing threat to European crayfish from nonindigenous crayfish species. Knowl Manag Aquat Ecosyst 394 395: 11

Hulme PE. 2009. Trade, transport and trouble: managing invasive species pathways in an era of globalization. $J$ Appl Ecol 46: 10-18.

Järvenpää T, Kirjavainen J. 1992. Crayfish stockings in Finland. Finnish Fish Res 14: 69-75.

Jussila J, Mannonen A. 2004. Crayfisheries in Finland, a short overview. Bull Français la Pêche la Piscic 372-373: 263-273.

Jussila J, Makkonen J, Kokko H, Mäkinen P. 2014. Numerous population crashes of Wild Signal Crayfish (Pacifastacus leniusculus) in Southern Finland. Freshw Crayfish 20: 73-79.

Jussila J, Vrezec A, Makkonen J, Kortet R, Kokko H. 2015a. Invasive crayfish and their invasive diseases in Europe with the focus on the virulence evolution of the crayfish plague invasive crayfish and their invasive diseases. In: Canning-Clode J, ed. Biological invasions in changing ecosystems. Berlin: De Gruyter Open Ltd, pp. 183-204.

Jussila J, Maguire I, Kokko H, Makkonen J. 2015b. Chaos and adaptation in the host-pathogen relationship in relation to the conservation: the case of the crayfish plague and the noble crayfish. In: Kawai T, Faulker Z, Scholtz G, eds. Freshwater crayfish: global overview. New Hampshire: Science Publishers, pp. 1-14.

Kirjavainen J, Sipponen M. 2004. Environmental benefit of different crayfish management strategies in Finland. Fish Manag Ecol 11: 213-218

Kirjavainen J, Westman K. 1994. Comparative growth from length composition and mark-recapture experiments for noble crayfish (Astacus astacus) and Signal crayfish (Pacifastacus leniusculus) in Finland. Nord J Freshw Res 69: 153-161.
Kouba A, Petrusek A, Kozák P. 2014. Continental-wide distribution of crayfish species in Europe: update and maps. Knowl Manag Aquat Ecosyst 413: 05.

Lodge DM, Taylor CA, Holdich DM, Skurdal J. 2000. Nonindigenous crayfishes threaten North American freshwater biodiversity: lessons from Europe. Fisheries 25: 7-20.

McCarthy JM, Hein CL, Olden JD, Jake Vander ZM. 2006. Coupling long-term studies with meta-analysis to investigate impacts of non-native crayfish on zoobenthic communities. Freshw Biol 51: 224-235.

Mueller GA, Carpenter J, Thornbrugh D. 2006. Bullfrog tadpole (Rana catesbeiana) and red swamp crayfish (Procambarus clarkii) predation on early life stages of endangered razorback sucker (Xyrauchen texanus). Southwest Nat 51: 258-261.

Nystrom P, Brönmak C, Graneli W. 1999. Influence of an exotic and a native crayfish species on a littoral benthic community. Oikos 85: $545-553$.

Ohtaka A, Gelder S, Kawai T, Saito K, Nakata K, Nishino M. 2005. New record and distribution of two North American branchiobdellidan species (Anelida:Clitellata) from introduced signal crayfish, Pacifastacus leniusculus, in Japan. Biol Invasions 7: 149-156.

Peters JA, Lodge DM. 2009. Invasive species policy at the regional level: a multiple weak links problem. Fisheries 34: 373-380.

Piria M, Copp G, Dick J, et al. 2017. Tackling invasive alien species in Europe II: threats and opportunities until 2020. Manag Biol Invasion 8: 273-286.

Rosenthal SK, Stevens SS, Lodge DM. 2006. Whole-lake effects of invasive crayfish (Orconectes spp.) and the potential for restoration. Can J Fish Aquat Sci 63: 1276-1285.

Ruokonen TJ, Karjalainen J, Hämäläinen H. 2014. Effects of an invasive crayfish on the littoral macroinvertebrates of large boreal lakes are habitat specific. Freshw Biol 59: 12-25.

Sandström A, Andersson M, Asp A, et al. 2014. Population collapses in introduced non-indigenous crayfish. Biol Invasions 16: 19611977.

Souty-Grosset C, Holdich D, Nöel PY, Reynolds JD, Haffner PH. 2006. Atlas of crayfish in Europe. Paris: Museum national d'Histoire naturelle.

Souty-Grosset C, Anastácio PM, Aquiloni L, et al. 2016. The red swamp crayfish Procambarus clarkii in Europe: impacts on aquatic ecosystems and human well-being. Limnologica 58: 78-93.

Vesely L, Hrbek V, Kozák P, Buřič M, Sousa R, Kouba A. 2017. Salinity tolerance of marbled crayfish Procambarus fallax $f$. virginalis. Knowl Manag Aquat Ecosyst 418: 21.

Walther GR, Roques A, Hulme PE, et al. 2009. Alien species in a warmer world: risks and opportunities. Trends Ecol Evol 24: 686-693.

Westman K. 1973. The population of crayfish, Astacus astacus L. in Finland and the introduction of the American crayfish Pacifastacus leniusculus Dana. Freshw Crayfish 1: 41-55.

Westman K. 2002. Alien crayfish in Europe: negative and positive impacts and interactions with native crayfish. In: Leppäkoski E, Gollash S, Olenin S, eds. Invasive aquatic species of Europe. Dordecht: Kluwer Academic Publishers, pp. 76-95.

Westman K, Savolainen R, Pursiainen M. 1999. Development of the introduced North American signal crayfish, Pacifastacus leniusculus (Dana), population in a small Finnish forest lake in 1970-1997. Boreal Env Res 4: 387-407. 